\title{
Müzik Öğretmeni Yetiştiren Kurumlardaki Öğrencilerin Keman Dersindeki Başarı Düzeylerini Yordayan Öğrenmeye İlişkin Özellikler ${ }^{1}$
}

\begin{tabular}{lccc}
\hline MAKALE TÜRÜ & Başvuru Tarihi & Kabul Tarihi & Erken Görünüm Tarihi \\
Araştırma Makalesi & 28.11 .2017 & 14.06 .2018 & 29.06 .2018 \\
\hline
\end{tabular}

Merih Doğan

Ankara Üniversitesi

Şeyda Çilden (iD) 3

Gazi Üniversitesi

Öz

$\mathrm{Bu}$ araștırmada Türkiye'de müzik öğretmeni yetiștiren kurumlarda keman dersi alan öğrencilerin, keman derslerindeki başarılarını yordayan (tahmin eden) öğrenmeye ilişkin özelliklerin belirlenmesi amaçlanmıştır. Araştırma korelasyonel bir araştırmadır. Çalışma 18 üniversiteden 521 lisans öğrencisi ile gerçekleştirilmiştir. Gerekli verilerin toplanmasında alanyazında bulunan "Bireysel Çalgı Performans Sınavı Kaygısı Ölçeği”, "Güdülenme ve Öğrenme Stratejileri Ölçeği”, "Öğrenme Biçemleri Envanteri”, "Öğrenme Yaklaşımları Ölçeği”, araştırmacı tarafından geliştirilen "Keman Dersine Yönelik Tutum Ölçeği” ve "Kişisel Bilgi Anketi" kullanılmıştır. Yapılan çoklu regresyon analizi sonucunda keman dersi başarısını yordayan özelliklerin sırasıyla öğrencilerin keman dersine yönelik tutumlarının, keman çalmaya başlama yaşlarının, mezun olduktan sonra yapmayı planladıkları mesleklerin, bireysel çalgı performans sınavı kaygılarının, günlük keman çalışma sürelerinin olduğu belirlenmiştir. Araştırmanın diğer değişkenleri ile keman dersindeki başarı arasında anlamlı bir ilişki saptanamamıştır. $\mathrm{Bu}$ sonuçlar doğrultusunda, öğretim elemanlarının bu etmenlere dikkat etmeleri, dersleri, başarıyı etkileyen değişkenleri göz ardı etmeden planlamaları ve gerçekleştirmeleri önerilmiştir.

Anahtar sözcükler: Keman dersi, keman dersi başarısı, müzik öğretmeni yetiştiren kurumlar, keman eğitimi, müzik eğitimi.

\footnotetext{
${ }^{1}$ Bu makale birinci yazarın doktora tezinin bir bölümünden üretilmiştir.

2 Sorumlu Yazar: Öğr. Gör. Dr., Güzel Sanatlar Fakültesi, Temel Sanat Eğitimi Bölümü, E-posta: merihdoganay@gmail.com, https://orcid.org/0000-0001-7455-5613

${ }^{3}$ Prof, Gazi Eğitim Fakültesi, Güzel Sanatlar Eğitimi Bölümü, Müzik Eğitimi Anabilim Dalı, E-posta: cilden@gazi.edu.tr, https://orcid.org/0000-0002-9441-0769
} 
İnsanların yaşamlarını sürdürebilmeleri, kendilerini geliştirebilmeleri için öğrenmeye gereksinimleri vardır. "Gagne (1985), öğrenmeyi; çevresel değişiklikler nedeniyle, bireyin duygu, düşünce ve ifadesinde meydana gelen diğer bir ifade ile insan karakterinde veya yeteneğinde sürekli olarak devam eden, büyüme sürecine atfedilmeyen bir değişim, olarak tanımlamıştır” (akt., Yüksel, 2013, s. 9).

Öğrenme ile ilgili olarak bütün bireylerin aynı özellikleri taşıdığı söylenemez. Bireylerin öğrenme hızları, öğrenme biçimleri birbirinden farklı olabilir. Öğrenme düzeylerini dışsal etmenlerin yanında içsel etmenler de etkileyebilir.

"Öğrenmeyi gerçekleştiren öğrencilerdir ve öğrencilerin tüm özellikleri öğrenmeyi olumlu ya da olumsuz yönde etkilemektedir. Öğrencinin nörofizyolojik, psikolojik ve fizyolojik özellikleri, öğrenmenin rotasını çizecektir. Bu da öğrenmede bireysel farklılıkları ön plana çıkarmaktadır” (Süral, 2008, s. 12).

Öğrenme ve başarının birbiri ile bağlantılı olduğu söylenebilir. Öğrencinin öğrenme düzeyi ne kadar gelişmişse, başarı düzeyi de o kadar artabilir. Dolayısı ile öğrenmeyi etkileyen etmenlerin öğrenci başarısını da belirlediği söylenebilir. "Başarı; insanın kendisi ve çevresiyle uyumlu yaşayabilmesi, kendini gerçekleştirebilmesi için belirli hedeflere ulaşırken gösterdiği çabalardan olumlu sonuçlar alması, şeklinde tanımlanabilir (Kaşlı, 2009). Eğitimde başarı ise genellikle akademik başarı olarak kabul edilir. Silah (2003) akademik başarıyı, öğrencilerin okul yaşamında amaçlanan davranışlara ulaşma düzeyi, olarak tanımlamaktadır" (akt., Canıdemir, 2013, s. 1).

Bireyleri başarıya ulaştırmanın yolunun, geçerli ve güvenilir yaklaşımlarla planlanan eğitimden geçtiği belirtilebilir. Fidan'a (2012) göre eğitim genel anlamıyla, insanları belli amaçlara göre yetiştirme sürecidir. Eğitimin boyutlarından biri, sanat eğitimidir. Sanat eğitiminin bir kolu olan müzik eğitiminin ise bazı boyutlarının olduğu bilinmektedir. Mesleki müzik eğitimi veren kurumlarda önemli bir yere sahip olan keman eğitimi, müzik eğitiminin boyutlarından olan çalgı eğitiminin bir dalıdır.

Bütün alanlarda olduğu gibi keman eğitiminde de başarıyı sağlayan etmenlerin neler olduğunun bilinmesi hem öğrenci hem öğretmen açısından önemlidir. Öğrenci, bu etmenlerin neler olduğunu bilerek bir çalışma düzeni oluşturabilir; öğretmen ise öğretim sürecini bu doğrultuda düzenleyebilir.

Keman eğitiminde öğrenci başarısı üzerinde etkili olabilecek değişkenlerden birisinin derse yönelik tutum olduğu belirtilebilir. "Allport'a (1935) göre tutum, yaşantı ve deneyimler sonucu oluşan, ilgili olduğu bütün obje ve durumlara karşı bireyin davranışları üzerinde yönlendirici ya da dinamik bir etkileme gücüne sahip duygusal ve zihinsel hazırlıklar durumudur" (akt., Tavşancıl, 2010, s. 65).

Öğrencilerin ders başarılarını etkileyebileceği düşünülen durumlardan biri de öğrencinin sınavlara yönelik olarak hissettiği kaygı düzeyidir. Müzik öğretmeni yetiştiren kurumlarda yapılan keman dersleri performansa dayalı olduğu için sınavları da performansın değerlendirilmesine yöneliktir. Bu bağlamda öğrencilerin bu dersin sınavına yönelik hissettikleri kaygı, performans kaygısı olarak da nitelendirilebilir. 
Öğrencilerin ders başarılarını etkileyen diğer bir değişkenin ise öğrencilerin benimsedikleri öğrenme yaklaşımlarının olduğu düşünülebilir. Spencer'e (2003) göre öğrenme yaklaşımı, öğrenenin öğrenme materyali ile nasıl etkileştĭgi ve bunu öğreneceği konu bağlamında nasıl düzenlediği ile ilgili temel yaklaşımını yansıtır.

Öğrencilerin benimsedikleri öğrenme yaklaşımlarının yanında kullandıkları öğrenme stratejilerinin de ders başarılarını etkileyeceği düşünülebilir. Öğrenme stratejileri genel olarak öğrenmeyi kolaylaştıran davranış ve düşüncelerin bütünü olarak tanımlanabilir. Öğrenme stratejileri, öğrenilecek bilgiye ilişkin temel düşüncenin belirlenmesi gibi basit çalışmalarla birlikte önceki öğrenilen bilgilerle ilişskiler kurularak yeni bilgilerin oluşturulması gibi karmaşı zihinsel süreçleri içerebilir (Weinstein ve Mayer, 1983; Weinstein, Ridley, Dahl ve Weber, 1989, s. 17). Pintrich ve diğerlerinin (1991) öğrenme stratejilerine yönelik yapmış olduğu sınıflamada bilişsel stratejilerden olan "Eleştirel Düşünme Stratejisi" keman dersi başarısı üzerinde etkili olabilecek bir değişken olarak düşünülebilir.

Öğrencilerin bireysel farklılıklarından biri olan öğrenme biçemlerinin de keman dersi başarısını etkileyen değişsenlerden olacağı düşünülebilir. "Öğrenme biçeminin, genellikle kabul edilen üç türü vardır. Bunlar bedensel (kinesthetic), işitsel (auditory) ve görsel (visual) biçemlerdir" (Şimşek, 2002, s. 36). Öğrenme biçemleri keman eğitiminde öğrenci başarısı üzerinde etkili olabilecek bir değişken olarak düşünülüp araştırma kapsamına alınmıştır. Bunların yanı sıra keman çalmaya başlama yaşının, mezun olunan okul türünün, günlük keman çalışma süresinin, yükseköğretime giriş sınavı puanlarının ve öğrencilerin mezun olduktan sonra yapmayı planladıkları mesleklerin keman dersi başarısı üzerinde etkili olabileceği düşünülebilir.

Müzik eğitimi alanında ve çeşitli alanlarda yapılan çalışmalar sınav kaygısı, derse yönelik tutum, öğrenme yaklaşımları ve öğrenme stratejileri ile öğrencilerin başarıları arasında bir ilişkinin olduğunu ya da öğrencilerin başarı durumlarına göre söz konusu değişkenlere sahip olma düzeyleri arasında anlamlı bir farklılık olduğunu ortaya koymuştur (Nacakçı ve Dalkıran, 2011; Piji Kü̧̈ük, 2010; Nalbantoğlu, 2007; Gergin 2010; Aydıner Uygun, 2013; Ekinci, 2008; İflazoğlu Saban ve Tümkaya, 2008; Şahin ve Çakar, 2011).

Müzik eğitimi alanında başarının mezun olunan lise türü, ÖSS puanları, özel yetenek sınavı puanları, ortaöğretim başarı puanları, günlük çalışma süreleri, öz yeterlik düzeyleri, güdülenme düzeyleri, benlik saygısı düzeyleri, çalgıya başlama yaşı, kişilik özellikleri, duygusal zeka, öğrenme süresinin uzunluğu, talimatları anlama yeteneği, bilişsel stratejiler, çevre, güdülenme, genel yetenek, ders sırasındaki farklı etkileşim kalıpları, öğretmenin uyguladığı yöntem, öğrenme stili, dışsal etmenler, içsel etmenler, çalışma süreçleri, başarı hedefi yönelimi gibi değişkenlerle olan ilişkileri ya da öğrencilerin başarı durumlarına göre söz konusu değişkenler arasında anlamlı bir farklılık olup olmadığı da araştırılmıştır (Ergün, 2006; Ece ve Sazak, 2006; Dalkıran ve Şaktanl1, 2009; Özmenteş, 2007; Piji Küçük, 2011; Çalışkan, 2008; Gürşen Otacıoğlu, 2009a; Gürşen Otacığlu 2009b; Özdemir, 2009; Çoraklı, 2007, Hallam, 1998; Pitts, Davidson ve Mcpherson, 2000; Williamon ve 
Valentine, 2000; Hallam, 2001; Jorgensen, 2002; Rostvall ve West, 2003; Mcpherson, 2005; Lammers, 2006; Rohwer ve Polk, 2006; Nielsen, 2008). Ayrica başarı ve performansa etki eden etmenlere ilişkin öğrenci ve öğretmen görüşünün değerlendirildiği çalışmalar da bulunmaktadır (Kılıç, 2003; Kılıç, 2006; Özmenteş, 2013; Erdinç, 2011; Hüseynova, 2014).

Araştırmalara bakıldığında, keman eğitiminde başarıya etkisi olduğu düşünülen öğrenme stratejileri, öğrenme yaklaşımları, öğrenme biçemleri, derse yönelik tutum, performans sınavı kaygısı, keman çalmaya başlama yaşı, mezun olduktan sonra yapmayı planladıkları meslekler, günlük keman çalışma sıklığı gibi özelliklerin hepsinin incelendiği korelasyonel bir araştırmaya rastlanmamıştır. Türkiye'de müzik öğretmeni yetiştiren kurumlar düzeyinde benzer bir çalışmanın yapılmadığı ve yapılan diğer çalışmalarda çoğunlukla farklı yöntemlerin kullanıldığı dikkat çekmektedir. Bu durum müzik öğretmeni yetiştiren kurumlarda, öğrenmeye ilişkin pek çok özelliğin çok değişkenli analiz yöntemleri kullanılarak başarı ile ilişkisinin ortaya konulduğu bu çalışmanın önemini artırmaktadır. $\mathrm{Bu}$ araştırmada ele alınan öğrenme biçemleri, öğrenme yaklaşımları gibi öğrenmeye ilişkin özelliklerin yanı sıra keman çalışma sıklığı, ileriye yönelik kariyer planları, kemana başlama yaşı gibi değişkenlerin ele alınmasının, keman dersi başarısının daha kapsamlı irdelenmesine katkı sağlayacağı düşünülmektedir.

$\mathrm{Bu}$ bilgiler 1şığında bu araştırmanın amacı, müzik öğretmeni yetiştiren kurumlarda keman dersi alan öğrencilerin keman derslerindeki başarı düzeylerini yordayan öğrenmeye ilişkin özellikleri belirlemektir. Bu genel amaç doğrultusunda aşağıdaki sorulara yanıt aranmışır:

Müzik öğretmeni yetiştiren kurumlarda "keman" dersi alan öğrencilerin

-Keman dersine yönelik tutumları

-Yükseköğretime Giriş Sınavı ham puanları

-İşitsel öğrenme biçemini benimseme düzeyleri

-Bedensel öğrenme biçemini benimseme düzeyleri

•Görsel öğrenme biçemini benimseme düzeyleri

-Derinlemesine öğrenme yaklaşımını benimseme düzeyleri

•Eleştirel düşünme öğrenme stratejisini benimseme düzeyleri

-Bireysel çalgı performans sınavına yönelik kaygıları

-Keman çalmaya başlama yaşları

•Günlük keman çalışma süreleri

-Mezun olduktan sonra yapmayı planladıkları meslekler (akademisyen olma, müzik öğretmeni olma vb.) 
-Mezun oldukları okul türleri, keman dersindeki akademik başarıyı anlamlı bir şekilde yordamakta mıdır?

\title{
Yöntem
}

Bu bölümde araştırmanın modeli, çalışma grubu, veri toplama araçları, verilerin toplanması, verilerin analizi konuları ele alınmıştır.

\begin{abstract}
Araştırma Modeli
$\mathrm{Bu}$ araştırma korelasyonel bir araştırmadır. Türkiye'de müzik öğretmeni yetiştiren kurumlarda keman dersini alan öğrencilerin bu dersteki akademik başarı puanları bağımlı değişken olarak ele alınmıştır. Öğrencilerin keman dersine yönelik tutumları, Yükseköğretime Giriş Sınavı puanları, işitsel, görsel ve bedensel öğrenme biçemini benimseme düzeyleri, derinlemesine öğrenme yaklaşımını benimseme düzeyleri, eleştirel düşünme öğrenme stratejisini benimseme düzeyleri, bireysel çalg1 performans sınavına yönelik kaygı düzeyleri, keman çalmaya başlama yaşları, günlük keman çalışma süreleri, mezun olduktan sonra yapmayı planladıkları meslekler ve mezun oldukları okul türleri yordayıcı değişken (bağımsız değişken) olarak ele alınmıştır. Bu araştırmada 13 yordayıcı değişken bulunmaktadır. Bu değişkenlerden ikisi (mezun olduktan sonra yapmayı planladıkları meslek, mezun oldukları okul türü) sınıflama düzeyinde kategoriktir. Diğer 11 yordayıcı değişken ise eşit aralık düzeyinde ve süreklidir. Keman dersine yönelik tutum değişkeni, alt boyutları dikkate alınarak iki ayrı yordayıcı değişken olarak araştırmaya alınmıştır. Böylece, 12 olan değişken sayısı 13'e yükselmiştir.
\end{abstract}

\section{Çalışma Grubu}

Araştırmaya 18 üniversiteden 535 katılımcı dahil edilmiştir. Toplanan veriler incelendiğinde 14 katılımcının veri toplama aracını özenli doldurmadığı veya çok sayıda yanıtsız madde bıraktığı belirlenmiştir. Bu nedenle araştırma için gerekli analizler 521 katılımcı üzerinden gerçekleştirilmiştir. Uygulama sürecinde bazı koşulların uygun olmamasından dolayı (pratik nedenler) seçkisiz örnekleme yoluna gidilememiş ve uygun örnekleme yöntemi kullanılmıştır. Zaman, para ve işgücü kaybını önlemeyi temel amaç edinen uygun örnekleme yönteminde araştırmacı, ihtiyaç duyduğu büyüklükteki bir gruba ulaşana kadar en ulaşılabilir olan yanıtlayıcılardan başlamak üzere örneklemini oluşturmaya başlar ya da en ulaşılabilir ve maksimum tasarruf sağlayacak bir durum, örnek üzerinde çalışır (Cohen ve Manion, 1989; Ravid, 1994) (akt., Büyüköztürk, Kılıç Çakmak, Akgün, Karadeniz ve Demirel, 2010). Çalışma grubuna dahil edilen üniversiteler ve katılımcı sayıları Tablo 1 'de verilmiştir. 
Tablo 1.

Çalışma Grubundaki Üniversiteler ve Katılımcı Sayıları

\begin{tabular}{llc}
\hline Sira Numarası & Üniversite & Katılımcı \\
\hline 1 & Yüzüncü Yıl Üniversitesi & 22 \\
2 & İnönü Üniversitesi & 26 \\
3 & Mehmet Akif Ersoy Üniversitesi & 21 \\
4 & Abant İzzet Baysal Üniversitesi & 14 \\
5 & Gazi Osman Paşa Üniversitesi & 31 \\
6 & Atatürk Üniversitesi & 41 \\
7 & Erzincan Üniversitesi & 32 \\
8 & Balıkesir Üniversitesi & 18 \\
9 & Uludağ Üniversitesi & 33 \\
10 & Marmara Üniversitesi & 38 \\
11 & Pamukkale Üniversitesi & 30 \\
12 & Cumhuriyet Üniversitesi & 15 \\
13 & Muğla Sitk1 Koçman Üniversitesi & 38 \\
14 & Harran Üniversitesi & 38 \\
15 & Niğde Üniversitesi & 28 \\
16 & Dokuz Eylül Üniversitesi & 25 \\
17 & Gazi Üniversitesi & 70 \\
18 & Necmettin Erbakan Üniversitesi & 15 \\
\hline Toplam & & 535 \\
\hline
\end{tabular}

Araştırma kapsamında hesaplanan aşamalı çoklu regresyon analizi dikkate alındığında 12 yordayıcı değişken için 521 katılımcının yeterli olduğu belirtilebilir. Field (2009) çoklu doğrusal regresyon analizinde her bir yordayıcı değişken için 15 bireyin yer almasının kabul edilen bir ölçüt olduğunu belirtmiştir.

\section{Veri Toplama Araçları}

Araştırmada gerekli verilerin toplanmasında kullanılan araçlar aşağıda kısaca açıklanmıştır.

Keman dersine yönelik tutum ölçeği. Bu araştırmada Doğan ve Çilden (2017) tarafından geliştirilen Keman Dersine Yönelik Tutum Ölçeği kullanılmıştır. Ölçek 5'li likert türünde 19 maddeden oluşmaktadır. Ölçeğin yapı geçerliği çalışması sonucunda iki faktörlü bir yapıya sahip olduğu belirlenmiştir. Birinci alt boyut 12 maddeden oluşurken, ikinci alt boyut 7 maddeden oluşmaktadır. Gerçekleştirilen doğrulayıcı faktör analizi çalışmasıyla iki faktörlü yapının doğrulandığı belirlenmiştir $\left(\mathrm{X}^{2} / \mathrm{sd}\right.$ : 2.72, NNFI: 0.95, CFI: 0.96, GFI: 0.86, AGFI: 0.82, RMSEA: 0.08). Geliştirilen ölçeğe yönelik Cronbach Alpha iç tutarlık katsayıları ise ölçeğin tamamı, birinci alt boyut ve ikinci alt boyut için sırasıyla $0.89,0.90$ ve 0.78 olarak hesaplanmıştır.

Bireysel çalgı performans sınavı kaygısı ölçeği. Ölçek, Dalkıran, Baltacı, Karataş ve Nacakçı (2014) tarafından geliştirilmiş ve geçerlik, güvenirlik çalışmaları yapılmıştır. 14 maddeden oluşan ölçek tek faktörlü bir yapı göstermektedir. Ölçek maddelerine ilişkin faktör yükleri .65 ve .84 arasında değişmektedir ve toplam 
varyansın \% 58'ini açıklamaktadır. Mevcut yapının doğrulanmasına yönelik gerçekleştirilen doğrulayıcı faktör analizi sonucunda tek faktörlü yapının doğrulandığg belirlenmiştir (X²/sd: 1.37, NFI: .96, CFI: .99, GFI: .94, RMSEA: .043). Ölçeğin Cronbach Alpha iç tutarlık katsayısı .94, test tekrar test güvenirlik katsayısı ise .93 olarak hesaplanmıştır. Bu araştırma kapsamında hesaplanan Cronbach Alpha iç tutarlık katsayısı ise 0. 94'tür.

Güdülenme ve öğrenme stratejileri ölçeği (GÖSÖ). Güdülenme ve Öğrenme Stratejileri Ölçeği (Motivated Strategies for Learning Questionnaire), Pintrich ve diğerleri (1991) tarafından geliştirilmiştir. Büyüköztürk, Akgün, Özkahveci ve Demirel (2004) tarafından Türkçe'ye uyarlanmış ve geçerlik, güvenirlik çalışmaları yapılmıştır. Güdülenme ve öğrenme stratejileri olmak üzere iki ayrı boyutta toplam 15 alt ölçekten oluşan GÖSÖ modüler bir yapıya sahiptir. Güdülenme boyutu altı faktörden oluşmakta ve toplam varyansın \% 56'sını açıklamaktadır. Hesaplanan doğrulayıcı faktör analizi sonucunda elde edilen bazı uyum göstergeleri (indeksleri) şöyledir: RMSEA: 0.06, GFI: 0.88, AGFI:0.85,CFI: 0.82, NNFI: 0.80. Öğrenme stratejileri boyutu ise dokuz faktörden oluşmakta ve toplam varyansın \% 53 'ünü açıklamaktadır. Hesaplanan doğrulayıcı faktör analizi ile elde edilen bazı uyum göstergeleri (indeksleri) şöyledir: RMSEA: 0.07, GFI: 0.80, AGFI: 0.77, CFI: 0.70, NNFI: 0.67, SRMR: 0.06 .

$\mathrm{Bu}$ araştırma kapsamında öğrenme stratejileri boyutunda yer alan "Eleştirel Düşünme Öğrenme Stratejisi” alt ölçeği kullanılmıştır. Bu alt ölçeğe ilişkin Cronbach Alpha iç tutarlık katsayısı 0.74 'tür. Bu araştırma kapsamında elde edilen verilerin Cronbach Alpha iç tutarlık katsayısı 0.75 olarak hesaplanmıştır.

Öğrenme biçemleri envanteri. Öğrenme Biçemleri Envanteri Şimşek (2002) tarafından geliştirilmiş ve geçerlik güvenirlik çalışmaları yapılmıştır. Üç faktörlü bir yapıya sahip olan ölçek maddeleri toplam varyansın yaklaşık \% 43'ünü açıklamaktadır. Envanter bedensel, işitsel ve görsel öğrenme biçemlerini kapsamaktadır. 48 maddeden oluşan ölçek, her öğrenme biçemi için 16 madde içermektedir. Ölçeğe ilişkin Cronbach Alpha iç tutarlık katsayıları bedensel, görsel ve işitsel öğrenme biçemleri için sırasıyla .684, .793 ve .771'dir. Araştırma kapsamında toplanan veriler bağlamında Cronbach Alpha iç tutarlık katsayıları bedensel öğrenme biçemi için 0.76, görsel öğrenme biçemi için 0.78 ve işitsel öğrenme biçemi için ise 0.74 olarak hesaplanmıştır.

Öğrenme yaklaşımları ölçeği. Ekinci (2008) tarafından geliştirilen ve geçerlik güvenirlik çalışmaları yapılan 5'li likert türünde olan "Öğrenme Yaklaşımları Ölçeği”" derinlemesine, yüzeysel ve stratejik öğrenme stratejileri olarak adlandırılan üç faktörlü yapı göstermektedir. Ölçek ile toplam varyansın \% 30.980’i açıklanmaktadır. Faktör yük değerleri 0.34 ile 0.75 arasında değişmektedir. Ölçeğin bütünü için hesaplanan Cronbach Alpha iç tutarlık katsayısı .85 olarak hesaplanmıştır. Derinlemesine öğrenme alt boyutu Cronbach Alpha iç tutarlık katsayısı .89, stratejik öğrenme alt boyutu .87 , yüzeysel öğrenme alt boyutu .82 olarak hesaplanmıştır. Bu araştırmada derinlemesine öğrenme yaklaşımı alt boyutu yordayıcı değişken olarak 
kullanılmıştır. Bu araştırmada elde edilen veriler bağlamında derinlemesine öğrenme yaklaşımı alt boyutu için hesaplanan Cronbach Alpha iç tutarlık katsayısı 0.89 'dur.

Kişisel bilgi anketi. Araştırmacı tarafindan geliştirilen bu araçta katılımcılara ait bazı demografik bilgilerin (keman çalmaya başlama yaşı, keman çalışma sıklığı, mezun olunan okul türü, Yükseköğretime Geçiş Sınavı puanı, keman dersi akademik başarı puanları vb.) elde edilmesi amaçlanmıştır. Veri toplama aracında yer alan maddelerin büyük kısmı kapalı uçlu iken keman çalmaya başlama yaşı, başarı puanı gibi değişkenlere ilişkin bilgiler katılımcılara açık uçlu olarak yöneltilmiştir. Kişisel bilgi anketi ile sınıflama ve sıralama ölçek düzeyinde veriler elde edilmiştir.

\section{Verilerin Toplanması}

Verilerin toplanması sürecine başlanmadan diğer araştırmacılar tarafından geliştirilen ölçeklerin kullanım iznine ilişkin yazışmalar yapılmıştır. Veri toplama sürecinde kullanılacak olan ölçekler bir araya getirilerek bir kitapçık oluşturulmuştur. Uygulama izni alınan üniversitelerin ilgili bölümlerinde uygulamalar yapılmıştır. Anket uygulamaları ortalama 20 dakika sürmüştür.

\section{Verilerin Analizi}

Araştırmanın bağımsız değişkenlerinin bağımlı değişkeni ne düzeyde yordadığını belirlemek için aşamalı çoklu regresyon analizi hesaplanmıştır. Analize geçilmeden önce örneklem büyüklügünün uygunluğu incelenmiş, çoklu bağlantı probleminin olup olmadığını test etmek için varyans büyütme faktörü, tolerans değerleri ve durum indeksi hesaplanmıştır. Çok değişkenli uç değerlerin belirlenmesi sürecinde Cook'un uzaklık katsayısı ve Mahalanobis değerleri hesaplanmıştır. Doğrusallık ve normallik varsayımı için standardize edilmiş yordanan değerler için oluşturulan histogram ve normal dağılım eğrileri incelenmiştir.

Çoklu regresyon analizinde çalışmada yer alan sürekli değiş̧enler analize doğrudan, kategorik değişkenler ise dummy değişkeni olarak kodlanıp analize dahil edilmiştir. Analiz sürecinde aşamalı çoklu regresyon hesaplanmış ve analize dahil edilen her bir değiş̧kenin mevcut varyansa katkısı gözlenmeye çalışılmıştır. Verilerin analizinde sosyal bilimlerde sık kullanılan ve aşamalı çoklu regresyon analizinin hesaplanabildiği bir paket bilgisayar programı kullanılmıştır.

\section{Bulgular}

Araştırmada verilerin çözümleme sürecinde aşamalı çoklu regresyon analizi hesaplanmadan önce gerekli varsayımlar test edilmiştir. Aşağıda test edilen varsayımlar ve sonuçları sunulmuştur.

\section{Örneklem Büyüklüğü}

Çok değişkenli bir analiz olan çoklu regresyon analizinde örneklem büyüklüğü öneme sahiptir. Bu süreçte yordayıcı değişken sayısı önemlidir. Her bir yordayıcı değişken için 15 bireyin yer alması kabul edilen bir ölçüttür (Field, 2009). Miles ve Shevlin (2001) 20 yordayıcı değişkene kadar 200 kişilik bir örneklemin orta 
büyüklükteki etkileri belirleyebilmek için yeterli olduğunu belirtmiştir. $\mathrm{Bu}$ araştırmada 13 yordayıcı değişken bulunmaktadır ve 521 kişilik örneklemde değişken başına yaklaşık 41 denek düşmektedir. Belirtilen her iki koşul için örneklem büyüklüğünün çoklu regresyonun hesaplanması için uygun olduğu belirtilebilir.

\section{Çoklu Bağlantı Problemi}

Çoklu regresyon hesaplanması sürecinde yordayıcı değişkenler arasında çok yüksek ilişsi olması istenmeyen bir durumdur. Bu araştırma kapsamında elde edilen bulgular incelendiğinde tolerans değerlerinin 0.37 ile 0.99 arasında değiştiği belirlenmiştir. Tolerans değerinin 1'e bölünmesi ile elde edilen varyans büyütme faktörü (VIF) değerlerinin ise 1.01 ve 2.7 arasında değiştiği gözlenmiştir. En yüksek durum index değeri ise 25.49 olarak hesaplanmıştır. $\mathrm{Bu}$ bulgular araştırma kapsamında yer alan yordayıcı değişkenlerin çoklu bağlantı problemi içermediğini göstermektedir (Myers, 1990).

\section{Uç Değerler}

Çoklu regresyon analizinde uç değerler tahmin edilen regresyon katsayısını etkilediğinden yanlılığa yol açabilir. Çok değişkenli uç değerlerin belirlenmesi sürecinde Cook'un uzaklık katsayısı incelenmiştir. Tüm değerlere ilişkin Cook'un uzaklık değerlerinin 1'in altında olduğu belirlenmiştir. Çok değişkenli uç değerlerin belirlenmesinde dikkate alınması gereken diğer bir değer ise Mahalanobis'in uzaklık değerleridir. Analiz sonucunda tüm değerlerin .05 anlamlılık düzeyi için 23.362'den küçük olduğu belirlenmiştir. Bu bulgular çok değişkenli uç değerlerin bulunmadığı şeklinde yorumlanabilir (Field, 2009).

\section{Doğrusallık ve Normallik Varsayımı}

Araştırmada yordayıcı değişkenlerin normallik ve doğrusallık varsayımları standartlaştırılmış tahmini değerler ile standartlaştırılmış hata (sapma) değerleri arasındaki grafiklerle test edilmiştir. Grafikler incelendiğinde değişkenlerin doğrusal ve pozitif yönde bir ilişkiye sahip olduğu gözlenmiştir. Ayrıca standardize edilmiş yordanan değerler için oluşturulan histogram ve normal dağılım eğrilerinin normale yakın bir dağılıma işaret ettiği belirlenmiştir.

$\mathrm{Bu}$ bulgular mevcut verinin aşamalı çoklu regresyon hesaplanması için uygun olduğunu göstermektedir. Araştırmada yer alan bağımsız değişkenlerin keman dersi başarısını yordama düzeylerinin belirlenmesi için aşamalı çoklu regresyon analizi hesaplanmıştır.

Çalışmada sürekli değişkenler analize doğrudan dahil edilmiştir. Kategorik değişkenler ise (Günlük keman çalışma süresi, Mezun olunan okul türü, Mezun olduktan sonra yapmayı planladıkları meslek) dummy değişkeni olarak kodlanıp analize dâhil edilmiştir. Araştırmaya toplam 13 yordayıcı değişken (İki faktörden oluşan tutum ölçeği iki ayrı değişken olarak düşünülmüştür.) dahil edilmiştir. Öğrencilerin keman dersi başarılarını anlamlı olarak yordayan değişkenleri 
belirlemeye yönelik hesaplanan aşamalı çoklu regresyon analizi bulguları Tablo 2'de sunulmuştur.

Tablo 2.

Keman Dersi Başarısını Yordayan (Tahmin Eden) Değişkenlere İlişkin Aşamalı Çoklu Regresyon Analizi Sonuçlarl $(n=521)$

\begin{tabular}{|c|c|c|c|c|c|c|}
\hline Aşama & Faktör & B & SHв & $\beta$ & $\mathbf{R}$ & $\begin{array}{c}\mathbf{R}^{2} \\
\text { Değgişim }\end{array}$ \\
\hline 1 & Keman Tutum Faktör 2 & .945 & .084 & $.443 * *$ & .443 & .196 \\
\hline \multirow[t]{2}{*}{2} & Keman Tutum Faktör 2 & .655 & .090 & $.307 * *$ & .516 & .069 \\
\hline & Keman Tutum Faktör 1 & .475 & .068 & $.297 * *$ & & \\
\hline \multirow[t]{3}{*}{3} & Keman Tutum Faktör 2 & .605 & .088 & $.284 * *$ & .562 & .050 \\
\hline & Keman Tutum Faktör 1 & .433 & .066 & $.271 * *$ & & \\
\hline & Keman Çalmaya Başlama Yaşı & -1.07 & .175 & $-.227 * *$ & & \\
\hline \multirow[t]{4}{*}{4} & Keman Tutum Faktör 2 & .555 & .087 & $.260 * *$ & .581 & .022 \\
\hline & Keman Tutum Faktör 1 & .397 & .066 & $.271 * *$ & & \\
\hline & Keman Çalmaya Başlama Yaşı & -.930 & .176 & $-.197 * *$ & & \\
\hline & $\begin{array}{ll}\text { Meslek } & \text { Seçimi(Müzik } \\
\text { Öğretmeni) } & \end{array}$ & -4.578 & 1.096 & $-.159 * *$ & & \\
\hline \multirow[t]{5}{*}{5} & Keman Tutum Faktör 2 & .521 & .088 & $.244 * *$ & .588 & .008 \\
\hline & Keman Tutum Faktör 1 & .400 & .065 & $.250 * *$ & & \\
\hline & Keman Çalmaya Başlama Yaşı & -.919 & .175 & $-.194 * *$ & & \\
\hline & $\begin{array}{l}\text { Meslek Seçimi( } \quad \text { Müzik } \\
\text { Öğretmeni) }\end{array}$ & -4.262 & 1.097 & $-.148 * *$ & & \\
\hline & Performans Sinav1 Kayg1s1 & -.090 & .036 & $-.093 * *$ & & \\
\hline \multirow[t]{6}{*}{6} & Keman Tutum Faktör 2 & .479 & .090 & $.225 * *$ & .593 & .006 \\
\hline & Keman Tutum Faktör 1 & .382 & .065 & $.239 * *$ & & \\
\hline & Keman Çalmaya Başlama Yaşı & -.916 & .174 & $-.194 * *$ & & \\
\hline & $\begin{array}{l}\text { Meslek Seçimi } \quad \text { (Müzik } \\
\text { Öğretmeni) }\end{array}$ & -3.986 & 1.102 & $-.138 * *$ & & \\
\hline & Performans Sınavı Kaygısı & -.089 & .036 & $-.091 * *$ & & \\
\hline & $\begin{array}{l}\text { Keman Çalışma Süresi } \\
\text { (1 saatten az) }\end{array}$ & -2.452 & 1.165 & $-.081 * *$ & & \\
\hline
\end{tabular}

Analize ilk aşamada keman dersi başarı puanları ile en yüksek ilişkiye sahip olan keman dersine yönelik tutum ölçeğinin ikinci faktörü dahil edilmiştir. Bu faktör, öğrencilerin ders dışında keman dersi ile ilgili yaptıkları çalışmalara ilişkin tutumlarını içermektedir. Öğrencilerin ders dışında keman dersi ile ilgili yaptıkları çalışmalara ilişkin tutumları, keman dersi başarı puanlarındaki toplam varyansın yaklaşık olarak \% 20'sini açıklamaktadır. Bu durumda ders dışında keman dersi ile ilgili çalışmalara yönelik tutumu olumlu olanların keman dersi başarı puanlarının daha yüksek olduğu belirtilebilir.

Analize ikinci aşamada keman dersine yönelik tutum ölçeğinin birinci faktörü dahil edilmiştir. Bu faktör öğrencilerin ders sırasındaki etkinlik ve durumlara yönelik 
tutumlarını içermektedir. $\mathrm{Bu}$ değişkenin keman dersi başarı puanına ait varyansa getirdiği katkı yaklaşık olarak \% 7'dir. Bu bulgu keman dersi sırasındaki etkinlik ve durumlara yönelik tutumları olumlu olan öğrencilerin keman dersi başarı puanlarının daha yüksek olduğunu işaret etmektedir.

Analize üçüncü aşamada keman çalmaya başlama yaşına ilişkin değişken dahil edilmiştir. Keman çalmaya başlama yaşı değişkeni, keman dersi başarı puanına ait varyansa \% 5'lik bir katkı sağlamıştır. Keman çalmaya başlama yaşı düştüğünde keman dersi başarı puanlarının arttığı belirtilebilir.

Analize dördüncü aşamada bir dummy değişkeni dahil edilmiştir. Bu kategorik değişken ile öğrencilerin mezun olduktan sonra yapmayı planladıkları mesleklerin keman dersi başarısını yordayıp yordamadığı belirlenmeye çalışılmıştır. Elde edilen bulgu, mezun olduktan sonra müzik öğretmeni olmayı planlayanların diğer meslekleri (müzik alanında akademisyen, orkestra elemanı vb.) tercih edenlere göre keman dersi başarı puanlarının daha düşük olduğu yönündedir. Bu değişkenin keman dersi başarı puanlarındaki varyansa \% 2 oranında bir katkı sağladığı belirtilebilir.

Analize beşinci aşamada bireysel çalgı performans sınavına yönelik kaygı değişkeni eklenmiştir. İlgili değişkenin keman dersi başarı puanına ait varyansa \% 0.8 'lik katkısı olmuştur. Bulgular dikkate alındığında bireysel çalgı performans sınavına yönelik kaygı düzeyindeki azalmanın keman dersi başarı puanında artışı sağladığı vurgulanabilir.

Analize altıncı ve son aşamada diğer bir kategorik değişken olan günlük keman çalışmaya ayrılan süre dahil edilmiştir. Bu değişken dummy değişkeni olarak kodlanıp analize dahil edilmiştir. Elde edilen bulgulara göre günde bir saatten daha az keman çalışanların akademik başarılarının, daha çok çalışan öğrencilere kıyasla daha düşük olduğu belirtilebilir.

Elde edilen bulgular altı yordayıcı değişkenin tamamının .01 düzeyinde anlamlı etkiye sahip olduğunu ve keman dersi başarı puanlarına ilişkin toplam varyansın \% 35.2'sini açıkladığını göstermektedir. Araştırmanın diğer yordayıcı değişkenlerinin keman dersi başarı puanları üzerinde anlamlı bir etkiye sahip olmadığı belirlenmiştir.

Elde edilen bulgularda öğrencilerin almış oldukları yüksek öğretime giriş sınavı ham puanlarının, mezun olunan okul türünün, derinlemesine öğrenme yaklaşımını benimseme düzeylerinin, eleştirel düşünme öğrenme stratejisini benimseme düzeylerinin, benimsedikleri öğrenme biçemlerinin anlamlı bir yordayıcı olmadığı belirlenmiştir.

\section{Tartışma, Sonuç ve Öneriler}

Araştırmada hesaplanan aşamalı çoklu regresyon analizi sonucunda keman dersindeki başarıyı yordayan değişkenler belirlenmiştir. Keman dersi başarı puanlarını yordayan en önemli değişkenin keman dersine yönelik tutum olduğu belirlenmiştir. Bu durum derse yönelik tutumları yüksek olan öğrencilerin ders başarılarının da yüksek olduğunu, ders başarısındaki en büyük etkinin derse yönelik 
tutumun olduğunu göstermektedir. Nalbantoğlu (2007), Karabulut (2009) araştırmalarında benzer bulgulara ulaşmışlardır.

Derse yönelik tutumdan sonra başarıyı yordayan diğer bir değişken keman çalmaya başlama yaşıdır. Bu sonuca göre keman çalmaya başlama yaşı düştükçe keman dersi başarısı artmaktadır. Sonucun bu doğrultuda çıkması beklenen bir durumdur. Özdemir'in (2009) araştırmasında da öğrencilerin gitar çalmaya başlama yaşlarına göre bireysel çalgı başarıları arasında anlamlı bir farkın olduğu belirlenmiştir. $\mathrm{Bu}$ farkın, daha erken yaşta başlayan öğrencilerin lehine olduğu saptanmıştır. Özdemir'in (2009) araştırmasında çıkan sonuç, bu araştırmanın bulgularını desteklemektedir.

Araştırmanın kategorik değişkenlerinden biri öğrencilerin mezun olduktan sonra yapmayı planladıkları meslektir. Bu bulgu mezun olduktan sonra müzik öğretmeni olmayı planlayan öğrencilerin, diğer meslekleri (müzik alanında akademisyen, orkestra elemanı vb.) yapmayı planlayan öğrencilere göre daha az başarı puanına sahip olduğunu göstermektedir. Bu durum öğrencilerin müzik öğretmenliği yaparken, diğer meslekleri yapanlara göre keman çalmaya daha az gerek duyacaklarını düşünmelerinden kaynaklanabilir. Bilen'in (2007) piyano öğrencilerinin başarılarına göre belirledikleri hedeflerin farklılık gösterip göstermediğini incelediği betimsel çalışmasının bulguları bir yönüyle bu araştırmayı desteklerken, bir yönü ile de bu araştırmanın bulgusuyla çelişmektedir.

Keman dersindeki başarı ile ilişkili olan bir diğer değişken bireysel çalgı performans sınavına yönelik kaygıdır. Bu sonuç doğrultusunda yüksek düzeyde kaygının başarıyı olumsuz yönde etkilediği belirtilebilir. Pek çok alanda olduğu gibi kayg1 düzeyinin yüksek olması keman dersindeki başarıyı da düşürmektedir. Nalbantoğlu'nun (2007) araştırmasında müziksel performans kaygısının performans başarısına etkisi araştırılmış, daha az performans kaygısı yaşayan öğrencilerin performans başarısının daha yüksek olduğu belirlenmiştir. Nacakçı ve Dalkıran (2011) ile Piji Küçük (2010) de benzer bulgulara ulaşmışlardır.

Başarı ile ilişkili olan son değişkenin günlük keman çalışma süresinin olduğu belirlenmiştir. Günde bir saatten az keman çalışan öğrencilerin daha çok çalışan öğrencilere kıyasla daha az başarı puanına sahip olduğu belirlenmiştir. Çalışma süresi arttıkça başarı düzeyi artmaktadır. Özmenteş'in (2007) çalışmasında benzer bulgulara ulaşılmıştır.

Tutum ölçeğinin iki faktörü ile birlikte toplam altı değişkenin keman dersi başarısı ile ilişkili olduğu belirlenmiştir. Tüm bu değişkenlerin toplam varyansın \% 35.2'sini açıkladığı belirlenmiştir.

Öğrencilerin Yüksek Öğretime Giriş Sınavı puanlarının, işitsel-görsel-bedensel öğrenme biçemlerini benimseme düzeylerinin, derinlemesine öğrenme yaklaşımını benimseme düzeylerinin, eleştirel düşünme öğrenme stratejisini benimseme düzeylerinin, mezun oldukları okul türlerinin keman dersindeki başarılarını yordamadığı saptanmıştır. Çeşitli araştırmalarda da benzer bulgulara ulaşılmakla 
beraber (Dalkıran ve Şaktanlı, 2009; Gergin, 2010; Topoğlu ve Ünal Öney, 2013; Çağlayan, 2007 ) bazı araştırmalarda farklı bulgular da elde edilmiştir (Gün, 2007; Aydıner Uygun, 2013; Ekinci, 2008; Canıdemir, 2013; Akbıyık, 2002; İflazoğlu Saban ve Tümkaya, 2008).

$\mathrm{Bu}$ bağlamda keman dersi veren öğretim elemanlarının öğrencilerinin tutumlarını arttırıcı birtakım etkinlikler gerçekleştirmeleri, velilerin ve öğretmenlerin keman çalmayı düşünen öğrencileri daha küçük yaşta keman çalmaya yönlendirmeleri önerilebilir.

Mezun olduktan sonra müzik öğretmenliği mesleğini yapmayı planlamayanların keman dersi başarısının öğretmenlik mesleğini yapmayı planlayanlara göre daha yüksek olduğu belirlenmiştir. Bu durum öğrencilerin öğretmenlik mesleğini yaparken nitelikli bir keman çalma becerisine gereksinim duymadıklarını düşündüklerinden kaynaklanabilir. $\mathrm{Bu}$ nedenle üniversite eğitimi sürecinde öğrencilere müzik öğretmenliği mesleğini yaparken nitelikli keman çalma becerisine sahip olmanın sağlayacağı katkılar anlatılabilir, gerekirse konuyla ilgili olarak seminerler, çalıştaylar düzenlenebilir.

Ayrıca öğretim elemanlarının sınav sırasında ve öncesinde öğrencilerin kaygılarını azaltacak davranışlarda bulunmaları ve sınav ortamını düzenlemeleri uygun olabilir. Bunun yanı sıra öğrencilerin keman çalışma sürelerini artırmak için etüt ve eser seçimlerine özen gösterilmesi yerinde olabilir. Benzer amaçla bölüm içerisinde öğrencilerin bireysel çalışmaları için gerekli olan fiziki olanaklar yoksa, bu olanakların oluşturulması ve iyileştirilmesi de öğrencilerin keman çalışma sürelerini artırabilir.

Benzer konuda çalışan araştırmacılara, başka değişkenleri de ele alarak değişkenler arasındaki doğrudan ve dolaylı etkileri ortaya çıkarabilecek yapısal modeller oluşturmaları ve daha ayrıntılı bilgiler elde etmek için görüşme, gözlem ve doküman incelemesine dayalı nitel araştırma desenlerini kullanmaları önerilebilir. 


\section{Kaynakça}

Akbıyık, C. (2002). Eleştirel düşünme eğilimleri ve akademik başarı. Yüksek Lisans tezi, Hacettepe Üniversitesi Sosyal Bilimleri Enstitüsü, Ankara.

Aydıner Uygun, M. (2013). Piyano dersindeki öğrenme yaklaşımları düzeyleri ile akademik başarı düzeyleri arasındaki ilişkilerin incelenmesi. The Journal of Academic Social Science Studies. 6(2), 1087- 1110. http://www.jasstudies.com/Makaleler/1180813348_59Ayd\%C4\%B1nerUygun Mehtap_S-1087-1110.pdf adresinden erişilmiştir.

Bilen, O. O. (2007). Öz-düzenleyerek piyano çalışmanin sınav performansına etkisi. Doktora tezi, Abant İzzet Baysal Üniversitesi Sosyal Bilimler Enstitüsü, Bolu.

Büyüköztürk, Ş., Akgün, Ö. E., Özkahveci, Ö., ve Demirel, F. (2004). Güdülenme ve öğrenme stratejileri ölçeğinin Türkçe formunun geçerlik ve güvenirlik çalışması. Kuram ve Uygulamada Eğitim Bilimleri, 4(2), 207-239. http://www.kuyeb.com/pdf/tr/de70726c1042202cc1beeb4916c24e50ozturk.PD $\mathrm{F}$ adresinden erişilmiştir.

Büyüköztürk, Ş., Kılıç Çakmak, E., Akgün, Ö. E., Karadeniz, Ş. ve Demirel, F. (2010). Bilimsel araştırma yöntemleri (6. Baskı). Ankara: Pegem.

Canıdemir, A. (2013). Ortaöğretim öğrencilerinin öğrenme yaklaşımları ve başarı amaç yönelimlerinin akademik başarı ile iliş̧isinin incelenmesi. Yüksek Lisans tezi, Ankara Üniversitesi Eğitim Bilimleri Enstitüsü, Ankara.

Çağlayan, H. S. (2007). Beden Ĕgitimi ve Spor Yüksekokulu öğrencilerinin öğrenme biçemleri ile problem çözme becerileri arasındaki ilişkinin incelenmesi. Doktora tezi, Gazi Üniversitesi Eğitim Bilimleri Enstitüsü, Ankara.

Çalışkan, T. (2008). Müzik öğretmeni adaylarının bireysel çalgı eğitiminde güdülenme düzeyleri ve başarı durumları arasındaki ilişki. Yüksek Lisans tezi, Marmara Üniversitesi Eğitim Bilimleri Enstitüsü, İstanbul.

Çoraklı, E. (2007). Müzik öğretmeni adaylarının piyano dersindeki başarıları ile kişilik özellikleri arasındaki ilişki. Yüksek Lisans tezi, Marmara Üniversitesi Eğitim Bilimleri Enstitüsü, İstanbul.

Dalkıran, E., Baltacı, H.Ş., Karataş, Z., ve Nacakçı, Z. (2014). Bireysel çalgı performans sınavı kaygı ölçeğinin geliştirilmesi: geçerlik güvenirlik çalışması. International Journal of Assessment Tools in Education, 1(1), 13-25. http://abs.mehmetakif.edu.tr/upload/0426_676_yayinDosya.pdf adresinden erişilmiştir. 
Dalkıran, E. ve Şaktanlı, S. C. (2009). Müzik eğitimi anabilim dalı öğrencilerinin başarılarına etki eden değişkenler arasındaki ilişkinin incelenmesi. Mehmet Akif Ersoy Üniversitesi Eğitim Fakültesi Dergisi, 9(17), 71-76. http://efd.mehmetakif.edu.tr/arsiv/haziran2009/pdf/090715.pdf adresinden erişilmiştir.

Doğan, M. ve Çilden, Ş. (2017). Keman Dersine Yönelik Tutum Ölçeğinin Geliştirilmesi, The Journal of Academic Social Science (Asos Journal), 5(57), 362-375.

http://www.asosjournal.com/Makaleler/2130284090_12970\%20Merih\%20DO $\%$ C4\%9EAN.pdf adresinden erişilmiştir.

Ece, A. S. ve Sazak, N. (Nisan, 2006). Özel yetenek stnavlarında ÖSS ve AOÖB puanlarının yerleştirme puanları içerisindeki yeri ve adayların ÖSS puanları ile akademik ortalamaları arasındaki ilişkilerin incelenmesi (AİBÜ örneği). Ulusal Müzik Eğitimi Sempozyumu'nda Sunulmuş Bildiri, Pamukkale Üniversitesi, Denizli. http://www.muzikegitimcileri.net/bilimsel/bildiri/pamukkale/EceSazak.pdf adresinden erişilmiştir.

Ekinci, N. (2008). Üniversite ögrrencilerinin öğrenme yaklaşımlarının belirlenmesi ve ögretme- ögrenme süreci değişkenleri ile ilişkileri. Doktora Tezi, Hacettepe Üniversitesi Sosyal Bilimler Enstitüsü, Ankara.

Erdinç, B. (2011). Güzel Sanatlar ve Spor Liselerinde keman eğitimindeki başarıyı etkileyen faktörlerin incelenmesi. Yüksek Lisans Tezi, Atatürk Üniversitesi Eğitim Bilimleri Enstitüsü, Erzurum.

Ergün, A. (2006). Marmara Üniversitesi Atatürk Eğitim Fakültesi Güzel Sanatlar Eğitimi Bölümü Müzik Eğitimi Anabilim Dalı'nı kazanan öğrencilerin mezun oldukları lise türüne göre, giriş sınavı puanları ile müzik teorisi ve bireysel çalgl derslerindeki başarı puanlarının karşılaştırılması. Yüksek Lisans Tezi, Marmara Üniversitesi Eğitim Bilimleri Enstitüsü, İstanbul.

Fidan, N. (2012). Okulda öğrenme ve öğretme (3. Bask1). Ankara: Pegem. http://pegem.net/dosyalar/dokuman/23022012131839\%C4\%B0nternet\%20\%C 3\%B6rnek.pdf adresinden erişilmiştir.

Field, A. (2009). Discovering statistics using SPSS (Third Edition). Sage. http://www.soc.univ.kiev.ua/sites/default/files/library/elopen/andy-fielddiscovering-statistics-using-spss-third-edition-20091.pdf adresinden erişilmiştir.

Gergin, Z. (2010). Bireysel çalgl 1 dersine ilişkin öğrenci tutumlarının ve başarılarının çeşitli değişkenler açısından incelenmesi. Yüksek Lisans Tezi, Mehmet Akif Ersoy Üniversitesi Sosyal Bilimler Enstitüsü, Burdur. 
Gün, E. (2007). Müzik öğretmeni adaylarının piyano derslerindeki başarı durumları ve başarllarını etkileyen faktörler. Yüksek Lisans Tezi, Süleyman Demirel Üniversitesi Sosyal Bilimler Enstitüsü, Isparta.

Gürșen Otacıoğlu, S. (2009a). Müzik öğretmeni adaylarının benlik saygısı düzeyleri ile akademik ve çalgı başarılarının karşılaştıılması. Dicle Üniversitesi Ziya Gökalp Eğitim Fakültesi Dergisi, 13, 141-150. http://www.zgefdergi.com/Makaleler/658500386_13_11_Otacioglu.pdf adresinden erişilmiştir.

Gürşen Otacıoğlu, S. (2009b). Müzik öğretmeni adaylarının duygusal zeka ile akademik ve çalgı başarı düzeyleri arasındaki ilişki. Fırat Üniversitesi Sosyal Bilimler Dergisi, 19(1), 85-96. http://web.firat.edu.tr/sosyalbil/dergi/arsiv/cilt19/sayi1/085-096.pdf adresinden erişilmiş̧ir.

Hallam, S. (1998). The predictors of achievement and droupout in instrumental tuition. Psychology of Music, 26, 116-132. http://journals.sagepub.com/doi/pdf/10.1177/0305735698262002 adresinden erişilmiştir.

Hallam, S. (2001). The development of expertise in young musicians: strategy use, knowledge acquisition and individual diversity. Music Education Research, 3(1), 7-23. http://www.tandfonline.com/doi/abs/10.1080/14613800020029914 adresinden erişilmiştir.

Hüseynova, L. (2014). Müzik öğretmenliği bölümü öğrencilerinin keman çalma performanslarını etkileyen bazı değişkenler. Bartın Üniversitesi Eğitim Fakültesi Dergisi, 3(1), 393-406. http://dergipark.ulakbim.gov.tr/buefad/article/view/1082000073/1082000087 adresinden erişilmiştir.

İflazoğlu Saban, A. ve Tümkaya, S. (2008). Öğretmen adaylarının öğrenme stratejileri ile sosyo-demografik özellikler ve akademik başarıları arasındaki ilişkinin incelenmesi. Ege Ĕ̈itim Dergisi. 9(1), 1-22. http://dergipark.ulakbim.gov.tr/egeefd/article/viewFile/5000004001/50000045 17 adresinden erişilmiştir.

Jorgensen, H. (2002). Instrumental performance expertise and amount of practice among instrumental students in a conservatoire. Music Education Research, $4(1), 105-119$.

http://www.tandfonline.com/doi/abs/10.1080/14613800220119804?journalCod $\mathrm{e}=$ cmue 20 adresinden erişilmiştir.

Karabulut, G. (2009). Eğitim fakültesi müzik eğitimi anabilim dalı 1. ve 3. sinıf ögrencilerinin piyano dersine yönelik tutumlarının incelenmesi. Yüksek Lisans Tezi, Gazi Üniversitesi Eğitim Bilimleri Enstitüsü, Ankara. 
K1lıç, I. (2003). Eğitim fakülteleri güzel sanatlar ĕgitimi bölümü müzik eğitimi anabilim dalı öğrencilerinin piyano eğitiminde başarlyı etkileyen faktörlere ilişkin görüşlerinin değerlendirilmesi. Yüksek Lisans Tezi, Gazi Üniversitesi Eğitim Bilimleri Enstitüsü, Ankara.

Kılıç, I. (Nisan, 2006). AGSL öğrencilerinin piyano derslerindeki başarı durumlarının değerlendirilmesi. Ulusal Müzik Eğitimi Sempozyumu'nda Sunulmuş Bildiri, Pamukkale Üniversitesi, Denizli. http://www.muzikegitimcileri.net/bilimsel/bildiri/pamukkale/I-Kilic.pdf adresinden erişilmiştir.

Lammers, W. (2006). Factors affecting performance proficiency: A case study involving intermediate piano students (Yüksek Lisans Tezi). http://rd.library.brocku.ca/bitstream/handle/10464/2793/Brock_Lammers_Will _2006.pdf?sequence $=1$ \&isAllowed=y adresinden erişilmiştir.

McPherson, G. E. (2005). From child to musician: Skill development during the beginning stages of learning an instrument. Psychology of Music, 33(1), 5-35. http://conservatoriosegovia.centros.educa.jcyl.es/sitio/upload/From_child_to_ musician.pdf adresinden erişilmiştir.

Miles J. ve Shevlin M. (2001). Applying regression and correlation: A guide for students and researchers. Thousand Oaks, CA: Sage.

Myers, R. H. (1990). Classical and modern regression application (2nd Edition). CA: Duxbury.

Nacakçı, Z. ve Dalkıran, E. (2011). Müzik Eğitimi Anabilim Dalı öğrencilerinin bireysel çalgı sınavına yönelik kaygıları. Mehmet Akif Ersoy Üniversitesi Sosyal Bilimler Enstitüsü $\quad$ Dergisi. $3(5), \quad$ 46-56. http://dergipark.ulakbim.gov.tr/makusobed/article/view/1098000409/10980002 77 adresinden erişilmiştir.

Nalbantoğlu, E. (2007). Yaylı çalgılar öğrencilerinin performansını etkileyen bazı faktörler ve ölçme değerlendirme yöntemleri üzerine bir araştırma. Doktora Tezi, Marmara Üniversitesi Eğitim Bilimleri Enstitüsü, İstanbul.

Nielsen, S. G. (2008). Achievement goals, learning strategies and instrumental performance. Music Education Research, 10(2), 235-247. http://www.tandfonline.com/doi/pdf/10.1080/14613800802079106?needAcces $\mathrm{s}=$ true adresinden erişilmiştir.

Özdemir, M. (2009). Müzik öğretmeni yetiştiren kurumlarda öğrenim gören gitar ögrencilerinin bireysel çalgl alan dersleri ve genel akademik başart durumlarının belirlenen değişkenler açısından incelenmesi. Yüksek Lisans Tezi, Abant İzzet Baysal Üniversitesi Sosyal Bilimleri Enstitüsü, Bolu. 
Özmenteş, S. (2007). Çalgı çalışma sürecinde özdüzenlemeli öğrenme ile duyuşsal özellikler ve performans düzeyi ilişkileri. Doktora Tezi, Dokuz Eylül Üniversitesi Eğitim Bilimleri Enstitüsü, İzmir.

Özmenteş, S. (2013). Çalgı eğitiminde öğrenci motivasyonu ve performans. Eğitim ve Öğretim Araştırmaları Dergisi, 2(2), 320-331. http://www.jret.org/FileUpload/ks281142/File/35._sabahat_ozmentes.pdf adresinden erişilmiştir.

Piji Küçük, D. (2010). Müzik öğretmeni adaylarının sınav kaygısı, benlik saygısı ve çalgı başarıları arasındaki ilişkinin incelenmesi. Ahi Evran Üniversitesi Eğitim Fakültesi Dergisi, 11(3), 37-50. http://dergipark.gov.tr/download/articlefile/15499 adresinden erişilmiştir.

Piji Küçük, D. (2011). Müzik öğretmeni adaylarının müzik yeteneğine ilişkin özyeterlik algıları özel yetenek sınavı başarıları ve akademik başarıları arasındaki ilişki. Marmara Üniversitesi Atatürk Ĕgitim Fakültesi Eğitim Bilimleri Dergisi, 34, 171-181. http://www.fppc.com.tr/download/articlefile/1915 adresinden erişilmiştir.

Pintrich, P. R., Smith, D. A. F., Garcia, T. ve McKeachie, W. J. (1991). A manual for the use of the motivated strategies for learning questionnaire (MSLQ). Ann Arbor, MI, National Center for Research to Improve Postsecondary Teaching and Learning. http://files.eric.ed.gov/fulltext/ED338122.pdf adresinden erişilmiştir.

Pitts, S., Davidson, J. ve Mcpherson, G. (2000). Developing effective practise strategies: Case studies of three young instrumentalists. Music Education Research, 2(1), 45-56. http://www.tandfonline.com/doi/pdf/10.1080/14613800050004422?needAcces $\mathrm{s}=$ true adresinden erişilmiştir.

Rohwer D. ve Polk, J. (2006). Practice Behaviors of eighth-grade instrumental musicians. Journal of Research in Music Education, 54(4), 350-362. http://journals.sagepub.com/doi/abs/10.1177/002242940605400407 adresinden erişilmiştir.

Rostvall, A. L. ve West, T. (2003). Analysis of Interaction and Learning in Instrumental Teaching. Music Education Research, 5(3), 213-226. http://www.tandfonline.com/doi/pdf/10.1080/1461380032000126319?needAcc ess=true adresinden erişilmiştir. 
Spencer, K. (2003, September). Approaches to learning and contemporary accounting education. Paper Presented at the Education in Changing Environment Conference Proceedings, Salfrod University. https://scholar.google.com.tr/scholar?q=Approaches+to+Learning+and+Conte mporary+Accounting+Education\&hl=tr\&as_sdt=0\&as_vis=1\&oi=scholart\&sa =X\&ved=0ahUKEwjr2PeazrPSAhWjDZoKHReeAMcQgQMIHDAA adresinden erişilmiştir.

Süral, S. (2008). Sınıf öğretmenliği öğretmen adaylarının ögrenme stilleri ile fen ve teknoloji ögretimi dersindeki akademik başarıları arasındaki ilişki. Yüksek Lisans Tezi, Pamukkale Üniversitesi Sosyal Bilimler Enstitüsü, Denizli.

Şahin, H. ve Çakar, E. (2011). Eğitim Fakültesi öğrencilerinin öğrenme stratejileri ve akademik güdülenme düzeylerinin akademik başarılarına etkisi. Türk Eğitim Bilimleri Dergisi. 9(3), 519-540. http://dergipark.gov.tr/download/articlefile/256206 adresinden erişilmiştir.

Şimşek, N. (2002). BİG 16 öğrenme biçemleri envanteri. Ĕgitim Bilimleri ve Uygulama Dergisi. 1(1), 33-47. http://www.ebuline.com/pdfs/1Sayi/1-3.pdf adresinden erişilmiştir.

Tavşancıl, E. (2010). Tutumların ölçülmesi ve SPSS ile veri analizi (4. Basım). Ankara: Nobel.

Topoğlu, O. ve Ünal Öney, E. (2013). Eğitim Fakültesi Güzel Sanatlar Eğitimi Bölümü öğrencilerinin eleştirel düşünme eğilimlerinin çeşitli değişkenlerle ilişkisinin incelenmesi. International Periodical For The Languages, Literature and History of Turkish or Turkic, 8(8), 1301-1312. http://docplayer.biz.tr/23665649-Egitim-fakultesi-guzel-sanatlar-egitimi bolumu-ogrencilerinin-elestirel-dusunme-egilimlerinin-cesitli-degiskenlerleiliskisinin-incelenmesi-ozet.html adresinden erişilmiştir.

Weinstein, C. E. ve Mayer, R. E. (1983). The teaching of learning stratgies. Innovation Abstracts, 5(32). http://files.eric.ed.gov/fulltext/ED237180.pdf adresinden erişilmiştir.

Weinstein, C. E., Ridley, D. S., Dahl, T. ve Weber, E. S. (1989). Helping students develop strategies for effective learning. Educational Leadership, 17-19. http://ascd.com/ASCD/pdf/journals/ed_lead/el_198812_weinstein.pdf adresinden erişilmiştir.

Williamon, A. ve Valentine, E. (2000). Quantity and quality of musical practice as predictors of performance quality. British Journal of Psychology, 91, 353-376. http://onlinelibrary.wiley.com/doi/10.1348/000712600161871/pdf adresinden erişilmiştir. 
Yüksel, G. (2013). Flüt öğretiminde psikolojik tip kuramına dayalı öğrenme stili odaklı ögretim uygulamalarının öğrenci başarısı düzeyine etkisi. Doktora tezi, Gazi Üniversitesi Eğitim Bilimleri Enstitüsü, Ankara. 


\title{
Characteristics Related To Learning As Predictors Of Student Success Level In Violin Lesson In Music Teacher Education Institutions ${ }^{1}$
}

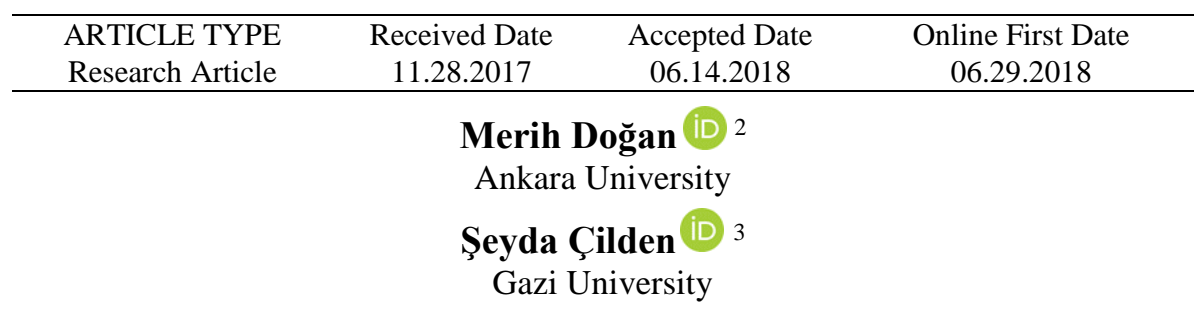

\begin{abstract}
In this study, it was aimed to determine the learning characteristics of the students, taking violin course in music teacher education institutions, which predict their success levels in violin lessons.The study was conducted with 521 undergraduates who attend violin lessons at 18 different music teacher education institutions. Study data were collected by using the "Individual Instrument Performance Anxiety Scale", "Motivated Strategies for Learning Questionnaire", "Learning Modality Inventory", "Learning Approach Inventory" and the "Attitude Scale towards Violin Lesson" developed by researcher and "Personal Information Questionnaire". Data analysis was carried out with multiple regression analysis. Results revealed that certain characteristics as students' attitudes towards the violin lesson, the age of beginning to play the violin, the professions they plan to perform after graduation, their anxiety level about the individual instrument performance exam, and violin practising time spent daily, respectively, are significant predictors of success in violin lesson. However, the other variables of the study were found not to have a significant relation with success level in violin lesson. As a result, it was suggested that instructors should consider these facts and plan and perform their classes without ignoring the variables affecting success.
\end{abstract}

Keywords: Violin lesson, success in violin lesson, music teacher education institutions, violin education, music education.

\footnotetext{
${ }^{1}$ This paper is derived from a part of $\mathrm{PhD}$ thesis of the first author thesis.

${ }^{2}$ Corresponding Author: Lecturer Dr, Faculty of Fine Arts, Department of Basic Art Education, E-mail: merihdoganay@gmail.com, https://orcid.org/0000-0001-7455-5613

${ }^{3}$ Prof, Faculty of Education, Department of Fine Arts Education, Division of Music Education, E-mail: cilden@gazi.edu.tr; https://orcid.org/0000-0002-9441-0769
} 


\section{Purpose and Significance}

In this study, it was aimed to determine the learning characteristics of university students which predict their success levels in violin lessons. In this direction, it was investigated whether students' success levels in violin lesson can be predicted by their attitudes towards the violin lesson, their anxiety level about the individual instrument performance exam, the age of beginning to play the violin, the professions they plan to perform after graduation, the type of school they graduated, violin practising time spent daily, raw scores obtained to take the Transition to Higher Education Examination, levels of adopting audio-visual-bodily learning styles, levels of adopting an in-depth learning approach, and levels of adopting critical thinking learning strategy. Results of this study will guide violin course instructors while planning and performing a violin course.

\section{Method}

This is a correlational study. The study was conducted with 521 undergraduates who attend violin lessons at 18 different music teacher education institutions. Study data were collected by using the "Individual Instrument Performance Anxiety Scale", "Motivated Strategies for Learning Questionnaire", "Learning Modality Inventory", "Learning Approach Inventory" and the "Attitude Scale towards Violin Lesson" developed by researcher and "Personal Information Questionnaire". Data analysis was carried out with multiple regression analysis.

\section{Results}

Results revealed that certain characteristics as students' attitudes towards the violin lesson, the age of beginning to play the violin, the professions they plan to perform after graduation, their anxiety level about the individual instrument performance exam, and violin practising time spent daily, respectively, are significant predictors of success in violin lesson. However, the type of school they graduated, raw scores obtained to take the Transition to Higher Education Examination, levels of adopting audio-visual-bodily learning styles, levels of adopting an in-depth learning approach, and levels of adopting critical thinking learning strategy variables were found not to have a significant relation with success level in violin lesson.

\section{Discussion and Conclusions}

In this study, the learning characteristics of university students predicting their success levels in violin lessons were determined. As a result, it was suggested that instructors should consider these facts and they should plan and perform their classes without ignoring the variables affecting success.

It was suggested researchers to test a model which shows direct and indirect effects among the variables with structural equation models. Moreover, quantitative studies should be done to get profound information about the factors related to students' success in violin courses. 